\title{
Surfaces
}

\section{Subsequent Precedence: Milton's Materialistic Reading of Ficino and Tasso}

\section{Marshall Grossman}

Volume 6, 1996

LES ÉCONOMIES DISCURSIVES DU SAVOIR ET DE LA CULTURE DANS LE SILLAGE DE L'OEUVRE DE BILL READINGS

THE DISCURSIVE ECONOMIES OF KNOWLEDGE AND CULTURE, WITH CONSTANT REFERENCE TO THE WORK OF BILL READINGS

URI : https://id.erudit.org/iderudit/1064863ar

DOI : https://doi.org/10.7202/1064863ar

Aller au sommaire du numéro

Éditeur(s)

Les Presses de l’Université de Montréal

ISSN

1188-2492 (imprimé)

1200-5320 (numérique)

Découvrir la revue

Citer cet article

Grossman, M. (1996). Subsequent Precedence: Milton's Materialistic Reading of Ficino and Tasso. Surfaces, 6. https://doi.org/10.7202/1064863ar
Résumé de l'article

Cet essai part de l'observation suivante de Bill Readings selon laquelle l'oeuvre de Milton a inauguré l'histoire moderne comme conception historique sans événement inaugural. De là, il touche à l'articulation metaleptique de l'origine et du terme, du Signifié et du Signifiant, dans la prose de Milton et il explore la performance rhétorique de l'idée d'imagination icastique de Platon, laquelle a convaincu Milton qu'écrire de la poésie est un travail social productif.
Copyright (c) Marshall Grossman, 1996

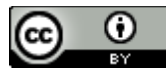

Ce document est protégé par la loi sur le droit d'auteur. L'utilisation des services d'Érudit (y compris la reproduction) est assujettie à sa politique d'utilisation que vous pouvez consulter en ligne.

https://apropos.erudit.org/fr/usagers/politique-dutilisation/ 


\title{
Subsequent Precedence: Milton's Materialistic Reading of Ficino and Tasso
}

\author{
Marshall Grossman \\ Dept. of English \\ University of Maryland \\ mg76@umail.umd.edu
}

Surfaces Vol. VI. 218 (v.1.0A - 08/09/1996) - ISSN:

1188-2492

Copyright for texts published in Surfaces remains the property of authors. However, any further publication should be accompanied by an acknowledgement of Surfaces as the place of initial publication.

\begin{abstract}
In departing from Bill Readings' view that Milton's work inaugurated modernist history as lacking an inaugurating event, this essay engages the metaleptic articulation of origin and terminus, meaning and signifier, in some of Milton's prose and explores the rhetorical performance of Plato's idea of the icastic imagination, which convinced Milton that writing poetry is socially productive labor.
\end{abstract}

\section{RÉSUMÉ}

Cet essai part de l'observation suivante de Bill Readings selon laquelle l'oeuvre de Milton a inauguré l'histoire moderne comme conception historique sans événement inaugural. De là, il touche à l'articulation metaleptique de l'origine et du terme, du Signifié et du Signifiant, dans la prose de Milton et il explore la performance rhétorique de l'idée d'imagination icastique de 
Platon, laquelle a convaincu Milton qu'écrire de la poésie est un travail social productif.

"Socrates ait: Cum iam id proprie assecuti sitis, queritis tamen"

- - Ficino, Commentary on the Philebus

"Time is the space of the preface; space - whose time will have been the Truth -

is the space of the preface. The preface would thus

occupy

the entire location and duration of the book."

- - Derrida, Disseminations

\section{POSTSCRIPT}

Balanced on "a fulcrum between predictive historical determinism and sheer contingency": an adventitious eruption of the uncanny into everyday life in which "the author bewails a learned friend".

Rereading Bill Readings while preparing this essay, I was stopped by a passage, appearing in a rejoinder to Richard Neuse's response to a paper on Milton and time that Bill presented at a conference in Florida. The conference was organized by the journal Exemplaria, which subsequently published Bill's essay under the title "'An Age to Late': Milton and the Time of Literary History" and his response to Neuse, under the title "Postscript: It's a Fair Cop."

In the passage in question, Bill refers to a headnote that Milton added to "Lycidas," his 1638 elegy for Edward King, when he republished it in 1645. The headnote, which resituates the poem as prophecy, reads: "In this Monody the Author bewails a learned Friend, unfortunately drown'd in his Passage from Chester on the Irish Seas, 1637. And by occasion foretells the ruin of our corrupted Clergy then in their height."

At the conference Neuse's response to Bill's talk raised issues about Eve's role in Paradise Lost that Bill had not raised. Realizing the senses in which Neuse's remarks could have been what he had meant all along, Bill remarks: 
We were all luckier than Edward King in our travel arrangements, so that our pretensions to the status of "genius of the shore" (184) on the Florida coast were of quite different order. Yet is it still possible to return to the past to discover what it "by occasion" foretold?

"By occasion" is a fascinating phrase: both referring to Lycidas as an "occasional poem," triggered by the event of King's death and offering it the status of an "occasion" in its own right, capable of prophecy. But also introducing a troubling ambiguity: does the very rigid prolepsis that prophetic foresight imposes itself proceed from chance occurrence, "by Occasion?" Does not the poem itself call for "lucky words" (20)? Milton's headnote thus positions the poem on a fulcrum between predictive historical determinism and sheer contingency. A curiously postmodern effect: we will have known what the meaning of our words was, but we will have a sense of their inevitable meaning only by chance. To put it another way, maybe I was talking about Eve, all along (490).

And to read this written out oral exchange - now? What had been speculative, reflective and constative, when I read it in 1992, became performative in 1994, and inescapably, claustraphobically so. In his work on Lyotard and on the literary history of the Renaissance, Bill often adverted to modernism as the moment in which the temporality or duration of the event is sacrificed to history, where its place in a succession marks its loss as an event:

The ground of historical accuracy within modernism, the possibility of dating an event, rests upon the replacement of the event qua happening by the event qua visible element within a historical schema of datability. And as such, all that the historical critic can do is blindly repeat the lack that characterizes her or his own present, so that writing history becomes the finding of loss more or less everywhere. The sense of history as having newly become visible is nothing less than the finding of history as the text of our own alienation, as a sense that the past is over, mere spectacle ("When Did the Renaissance 
Begin?", 297; see also, Introducing Lyotard, pp. 53-63).

For Bill, Milton's work inaugurated modernist history as a history lacking an inaugurating event, and attained a fitful postmodernity by thematizing the incommensurability of the diachrony of the event and the synchronic structure of history in which the event must always already take its place (see, for example, "'An Age Too Late': Milton and the Time of Literary History"). The following essay, first drafted in 1986, intended as part of book to be (re)written next year, and revised through and by the present occasion for a reading and a rereading of Bill Readings, engages - - precisely as a literary historical event - the metaleptic articulation of origin and terminus, meaning and signifier, in some of Milton's prose. As an attempt at literary history, which can only mark the history of the iterative moments in which literature becomes history, it undertakes to examine and give duration to the mediations by which Milton (and my commentary on him) enter history by following that which follows from them, and thus - like this (first) prefatory postscript - preceding themselves. Circumstantially, "it's a Fair Cop."

I take the first of my two epigraphs from Ficino's commentary on the Philebus. I will translate it as "Socrates says: Although you have followed it properly, you seek it still," or, perhaps a bit more contextually, "Although you have properly followed [my argument], you continue to question."[ 1 ] I have placed this sentence, which will reappear in the body of my text (in Michael Allen's slightly less literal translation), in its present prefatory position, because it aptly establishes one of the contexts in which I wish to set the following excerpt from the history of the distinction made, among other places, in Plato's The Sophist, between the icastic and the phantastic imaginations, as it was reborn and remodeled in the applications of some Renaissance poets. This distinction figured largely in the continental debate over Orlando Furioso, and played an important role in Tasso's Discorsi del poema eroico, from whence it came also to Spenser and Milton. In brief, the icastic faculty imitates things which are, whether or not they may be sensed, while the phantastic faculty "imitates" non-existent things (Tasso, 29). 
By considering a few of the changes this idea underwent as it traversed Europe and the Renaissance from quattrocento Florence to seventeenth-century London, I mean to address the very specific literary historical issue of how Renaissance writers silently revised a classical notion so as to preserve its usefulness as a precedent through changing contemporary circumstances. Insofar as an abiding theme of Bill Readings' work is the resistance of the literary to the reduction - "by occasion" - of performance to idea, I want also to use this expedition into the literary history of the Renaissance as a way of addressing the more general question of the temporality of the concept. When we follow an argument, at what point do we appreciate its premises as premises? If the argument is presented in literature, at what point (if any) is the literary performance superseded by the "idea" it "represents"? Or, To put this question closer to the form it had when Aristotle revised Plato's forms by making them immanent in particulars: Do concepts precede or follow from things?[ $\underline{\mathbf{2}}$ ]

My second epigraph, a comment of Derrida's on the preface to Hegel's Phenomenology of the Spirit, reaches toward this wider context.[ $\underline{\mathbf{3}}$ ] My literary historical concern in this essay will be to explore the rhetorical performance of the idea of an icastic imagination in convincing Milton that writing poetry is socially productive labor, but I want also to suggest that the epigraphic movement from Ficino's paraphrase of Plato to Derrida's paraphrase of Hegel marks also the historicity of what Derrida has called the logic of the supplement (159-71), the representation that substitutes for the being-as-presence of Truth, but also marks its absence, and, without fully arguing the case on this occasion, I want, at least, to call attention to the utility of supplying the logic of the supplement with an (admittedly supplementary) history of its own emergencies and concealments. Or, and still more broadly, I want to insist on the literariness of literary history.

Thus the broader argument underlying these remarks is that - by occasion - in the seventeenth century, a particular conjunction of act, thought, and time came into play, in a determined relation to a determinate coming to consciousness of the play of the supplement over the place of the origin. If between the "original" and its representation, there is a complicity amounting to the reversibility of original and copy, it remains significant that the deferral of the "original" with respect to a representation that anticipates, enables and 
subsequently defers its appearance, became, in a given set of exigent circumstances, a theme of Renaissance poetics.[ $\underline{\mathbf{4}}$ ] Within the compass of this theme, the temporalizing non-identity that underlies and structures signification - what Derrida calls différance - is written out and recuperated as a deferred or latent structure. My large claim, of which this argument forms only a partial justification, is that by conceiving of the course of human events, what Milton calls, "the Race of time," as a temporal detour through which humankind collectively proceeds toward a fully significant structure of knowledge, the Renaissance (retrospectively) reconstructs its sources in the direction of a modern - that is a historical - conception of human agency.

It is common to think of the Renaissance as opening a new phase in human history. In fact, it is, significantly, the fashion among historians to mark its affinity with our age by referring to it as the early modern period. I want specifically to locate a significant aspect of the modernity of the early modern period in a change, observable in the sixteenth and seventeenth centuries, in the temporality of the concept, that is, in the structure of time according to which an argument is made or followed. I want, then, to take a closer look at how modernity happened.

At the same time, I want to take the early modern works I will be discussing at their word in trying to understand in what sense the classical idea of the Icastic imagination is re-born in the Renaissance to become a precedent for the very works in which it will be established and from which it will follow. Therefore, I will try to be attentive to the continuity of change, to the ways in which the truly new enters intellectual life in the costume of the ancient. For reasons that, if they are not clear now, will become clear in the course of this discussion, I will start near the end of my story and work backward.

\section{2}

In a famous passage from the tractate "Of Education," Milton, spelling out a paedeia of studies by which young boys are to be formed into governors, counsellors and clergymen (Prose 2,406), cites the sources of a rhetorical poetics to which he accords a curiously ambiguous place in the curriculum of his ideal school: 
Logic therefore so much as is usefull, is to be referr'd to this due place withall her well coucht heads and Topics, untill it be time to open her contracted palm into a gracefull and ornate Rhetorick taught out of the rule of Plato, Aristotle, Phalareus, Cicero, Hermongenes, Longinus. To which Poetry would be made subsequent, or indeed rather precedent, as being lesse suttle and fine, but more simple, sensuous and passionate. I mean not here the prosody of a verse ... but that sublime art which in Aristotle's poetics, in Horace, and the Italian commentaries of Castelvetro, Tasso, Mazzoni, and others, teaches what the laws are of a true Epic poem, what of a Dramatic, what of a Lyric, what decorum is, which is the grand master peece to observe. This would ... shew them, what Religious, what glorious and magnificent use might be made of Poetry both in divine and humane things. (Prose, 2.402-6)

This use of the analogy of the closed fist to the open hand to relate logic to rhetoric as the tools by which Truth is respectively determined and explained is commonplace. But the tractate responds to a request for a practical curriculum, and anyone wishing to enact Milton's program might well stumble over the words "To which Poetry would be made subsequent, or indeed rather precedent." How does this disjunctive phrase play out as pedagogical practice? Do the boys study poetics after the study of logic and rhetoric or before? We are told elsewhere in the tractate that the poets are to be read as soon as sufficient (classical) language has been acquired. But the unactable rhetorical reversal in Milton's "subsequent or indeed precedent" superimposes a logical structurality on the necessarily temporal one foot before the other of its pedagogical steps (paedeia). Is poetry logically prior to the theories that ostensibly govern its practice; that is, to logic, rhetoric and poetics? This very broad question conceals within it the even broader question of whether the laws of discourse are immanent in the particular examples from which they are induced, or logical in the Platonic and Thomistic sense of being prior to, and enabling of, discourse as such. What is the connection, if any, between, logical and temporal sequitor, between following from, and following after? Milton's comments on these issues are of interest not only because they supplement his poetic practice but also for the opportunity they afford of investigating the ways in which traditional and 
commonplace ideas are adapted and transformed to suit historically determined needs: the way in which "lucky words" turn out to have been prophetic. In this particular case, I shall be underlining a turn or re-turn of the Neoplatonic tradition toward the material world and the human body, a break with classical, medieval and high Renaissance thought that is registered by Milton as a continuity.

Milton makes an understanding of the divine and human uses of poetry the capstone of his educational program, arguing that only when young scholars appreciate the uses of poetry do they attain the "universal insight into things" that will enable them to become the poets, orators and preachers of an ideal republic (406). But how, precisely, does an understanding of the uses of poetry open into a universal insight into things, and through what sort of processes? When it turns to rhetorical poetics, Milton's very practical response to Hartlib's query on the reform of education engages some very fundamental philosophical issues, and necessarily so, since, in Milton's view:

The end of learning is to repair the ruins of our first parents by regaining to know God aright, and out of that knowledge to love him, to imitate him, to be like him, as we may the neerest by possessing our souls of true vertue, which being united to the heavenly grace of faith makes up the highest perfection. But because our understanding cannot in this body found it selfe but on sensible things, nor arrive so cleerly to the knowledge of God and things invisible, as by orderly conning over the visible and inferior creature, the same method is necessarily to be follow'd in all discreet teaching. (Prose, 2.366-7)

When we consider that the end of learning is to return to the beginning, that is, to the knowledge of God that preceded the Fall, and that the method of this return must be through the body and its sensory understanding of things, we begin to appreciate the importance of the ambivalence between priority and origin and between logical and temporal sequence that surfaces in Milton's discussion of poetics. This ambivalence informs his work on two levels: 1) It represents the distinction of two dialectically related kinds of knowing, both necessary "to repaire the ruins of our first parents" and "know God aright"; and 2) It represents the intersection of logical and temporal priority in such a way as to accommodate 
the view, gaining ground in the seventeenth century, that human history is an arena in which a revelation of God's eternal design unfolds in time - as and through human endeavor (Grossman, "Authors to Themselves"). If the knowledge of God from which man fell must be reclaimed through the union of sense and intellect, education must remember this forgotten beginning by refounding the poetry of Eden on the poetry of the body. This dialectical reclamation of intelligence through sense is socially powerful because it implies that the logical causes of things will be discovered in their temporal ends - in the rhetorical closure they effect by ceasing to be.

That there are two distinct kinds of knowledge, one available through the body, the other apprehended by a higher, rational faculty, descends, of course, from Plato's distinction between sense and intelligence. What interests me in Milton's recension of the doctrine is the very particular way in which his insistent monism overcomes Platonic dualism by envisaging a dialectical linkage between sense and intelligence, so as to represent knowledge of worldly things as a historical route to a universal and atemporal insight. By situating Christian man at the intersection of historical retrospection and divine revelation, Milton allows the particularity of human experience to participate in the revelation of universal design. The process that underlies this exchange of qualities between the eternal and the historical is, strictly speaking, a rhetorical one.

Milton's assertion of a poetic practice at once subsequent and precedent to theoretical knowledge opens the way to a rhetoric of prophecy that substitutes the representation of prophecy for prophecy itself so as both to accomplish and attempt to justify the sacrifice of immediacy to the practice of historical interpretation. As, in the closing books of Paradise Lost, Michael teaches Adam to remember his "nobler end" of "conformity divine" by understanding scenes of his worldly future $(11,605-6)$, Milton expects his prophetic poetry to instruct its readers in the dialectic of a providential history, the precedent of which is revealed in Scripture and sensibly written in and by the subsequent acts of Christians living out the "race of time."

For Milton the poetic cultivation of the soul is a social project entailing the cultivation of this world (Grossman, "The Fruits of One's Labor"). Thus he reports in the Reason of Church Government that he must justify the "ease and leasure ... given [him] for [his] retired thoughts out of the sweat of other men" by using his 
talents to advance the cause of "God and his Church" (Prose 1, 804).[ $\underline{\mathbf{5}}$ ] This "Ease and leasure" he quickly transforms into the "labour and intent study . . . joyn'd with the strong propensity of nature" by which he hopes to "leave something so written to aftertimes, as they should not willingly let it die" $(1,810)$. By cultivating his mind, the poet prepares to bring forth a poem that will be "doctrinal and exemplary to a Nation" $(1,815)$ and cultivate in its readers a sensible revelation of intellectual truth.

Milton found a precedent for this "transubstantiation" of sensible experience into intellectual ideas in the confluence of the ancient distinction between icastic and phantastic imagination to which I have referred and the reformation tendency to use typology to interpret not only the Hebrew Scriptures but contemporary historical events as well.

Though Milton was doubtless aware of the division of the imagination into phantastic and icastic faculties in Plato and Isocrates, a more immediate source was certainly Tasso's Discourses on the Heroic Poem. This text provides a convenient statement of the claim for icastic representation with respect to the content of heroic poetry in the Renaissance. Briefly stated, the argument for icastic poetry begins with the Aristotelian doctrine that all poetry is imitation and then divides poetry that imitates figments of the poet's phantastic imagination from poetry that imitates true things, as they are conceived through the faculty of the icastic imagination. Although the icastic imagination imitates true things, it differs from history in so far as the true things it imitates need never have been apprehended by the senses; it produces, paradoxically, the sensible sign of a truth that exceeds the senses and may be grasped only with the intellect, providing a sensible stimulus to intellectual progress. Tasso writes:

If images are of existing things, this imitation belongs to the icastic imitator. But what shall we say exists, the intelligible or the visible? Surely the intelligible, in the opinion of Plato too, who put visible things in the genus of nonbeing and only the intelligible in the genus of being. Thus the images of angels that Dionysius describes are of existences more real than all things human. So too the winged lion, the eagle, ox, and angel, which are images of the evangelists, do not belong principally to phantasy and are not its proper objects, since phantasy is [a faculty] in the divisible part of 
the mind, not the indivisible, which is the intellect pure and simple, unless besides the phantasy which is the faculty of the sensitive soul there were another which is a faculty of the intellective. (32)

Although, according to Tasso, the poet may "imitate things that are, were, or may be" (30), it is the movement from intellectual idea to material poetic image that extends the scope of poetry from imitation of historical events to that of an instrument through which the poet's socially productive labor puts "God's entrusted gifts" to use: "[The poet] is a maker of images in the fashion of a speaking painter, and in that is like the divine theologian who forms images and commands them to be" (31). Mystical theology and poetry thus meet in the moment in which the ideal becomes image; they differ, however, in that the poet's making of images is a physical act, engaging verbal material and having duration, while the mystical sign remains immediate, indivisible and non-sensory:

And if dialectic and metaphysics, the divine philosophy of the pagans, have such similarity that the ancients thought them the same, no wonder that the poet is almost the same as the theologian and the dialectician. But divine philosophy, or theology as we may prefer to call it, has two parts, each of them fitting and proper to one part of the mind, which is composed of the divisible and the indivisible, according to not only Plato and Aristotle, but the Areopagite also, who wrote . . . that the part of the most occult theology which is contained in signs and has the power to perfect, belongs to the indivisible mind, which is intellect pure and simple. The other part, eager for wisdom, which uses demonstration, he assigns to the divisible mind, much less noble than the indivisible. Now to lead to the contemplation of divine things and thus awaken the mind with images, as the mystical theologian and the poet do, is a far nobler work than to instruct by demonstration, the function of the scholastic theologian. (31-2, my emphases)

Tasso's comparison of the poetry of the icastic imagination to speculative theology on the one side and "mystical theology" on the other explains Milton's assertion, in "Of Education," that poetry is the better teacher because it is "more simple sensuous and 
passionate" (Prose 2, 403). The scholastic theologian appeals, through speculative concepts, to the intellectual faculty alone, but the poet, like the mystical theologian, appeals to the senses and links them to the intellect, thereby conducting his reader from sensible signs to a "universal insight into things." Poetry, then, is a medium through which the indwelling spirit is materially expressed and communicated, and, since its immanent rules must be mastered before it can be effectively employed, it is at once the product and the source of the dialectical arts of logic and rhetoric. The thing itself - as idea - precedes the icastic sign which subsequently discovers it and through which it has its efficacy. Mastery of the rhetoric of prophecy allows the discovery (or, in the terms of classical rhetoric, the invention) of intellectual truth and the disposition of that truth in the form of sensible signs that will transmit the truth to a reader. Things are given to signs that signs might discover things.

This elevation of poetic material to the spirit may be understood as the allegorical statement of a linguistic insight. Words are the medium of poetry, and words do indeed mediate mental concepts among the participants in a conversation. The specificity of the signifier coupled to the generality of the signified, the fact that the word "tree," for example, will evoke in a number of auditors a great variety of mental images of trees, while putting into discursive circulation a generalized notion of treeness, parallels the socially productive power of icastic poetry to bring into material being a communally recognized ideal.

Moreover, every particular use of language relies on and brings into play some part of the system of rules that make up a given language in much the way that Tasso's poetic image is a particular and sensible event that puts in play, derives its "true" significance from, the divine design, in its eternal completeness. The system of relations among sounds that is language precedes and underlies any meaningful discourse, but, at the same time, it is through the audible expressions we recognize as intelligible speech that the system of language comes to be known.[ $\underline{\mathbf{6}}$ ]

The image of this state of affairs is reflected in the mimetic mirror of Tasso's poetry of the icastic imagination. Human life is a historical episode encompassed by and expressing itself within the universal and eternal design of divine providence. Each episode becomes meaningful, becomes, legible, only with 
respect to the whole design; each historical event speaks as an episode in the advance of history toward the apocalypse, at which time history's sentence will be complete and, its meaning fixed, and, at which time, the subject of its narration will disappear.

\section{3}

We need not look ahead from Milton to Saussure to find the analogy of language to the structure of an ideally ordered universe. In the Philebus (17a-c), Plato introduces the example of alphabetic writing to illustrate the articulate relationship of the many particulars to the ideal whole in which they are subsumed. Because I am here concerned with Tasso's reception of the doctrine and its context in Italian Renaissance poetic theory, I quote, following Tasso's suggestion, Ficino's paraphrase of the passage:

[Hermes (Ficino's identification of Plato's Thoth)] divided letters so that he could arrive at individual letters; and each separate letter he called an "element," that is, an element of a syllable. He also called letters as a whole an element, that is, an element of diction and of speech. But as he reflected nobody would know any one letter without knowing them all (that is, nobody could know the power of any one letter without linking it with the others, or could distinguish clearly the nature of the one common voice without the individual voices), accordingly, he divided the one voice into many letters. And he intertwined any letter with others in such a way that he introduced the one discipline of dividing and joining. This discipline, which was concerned with the common nature of the letters and their mutual relationships, he called grammar. (274)

In the Philebus, Protarchas, failing to grasp the relevance of Socrates' account of grammar to the question of whether wisdom is superior to pleasure, accuses Socrates of digressing. Ficino paraphrases Socrates' rebuke as follows:

"Though, in actual fact, you know the answer already, you keep asking. For this long investigation means, since we have to decide 
between pleasure and wisdom (which of them ought to be chosen preferably as the better one), we must understand them both first by knowledge [prius scientia]. But since each is a genus divided into many species (and the species are again divided into an infinite number of single things), the higher discipline requires we consider how both must be divided into definite species and in what order, before we descend to the infinite number of single things." (274-6)

Socrates and Ficino go on to explain that dialectic (as if it were a universal grammar) is the tool through which genus and species may be joined at the higher level of their ideal unity. Thus the example of grammar is to be taken as paradigmatic of the relationship of all particulars to the ideal unity in which they participate. But, always already embedded in this question of the articulation of particulars to a virtual formal structure is the question of the relation of time to structure "Though, in actual fact, you know the answer already, you keep asking, .... We must understand them both first by knowledge.... We consider how both must be divided into definite species and in what order, before, we descend to the infinite number of single things." How is it that a perfect, synchronic structure discloses itself only through a fixed temporal sequence? Where is the time of its discovery in relation to the comprehensive order this ordered sequence reveals? Is the concept of precedence subsequent or precedent to the system that sustains it?

Milton's version of the icastic faculty rewrites this tension between logical and temporal priority, this need to know the particular by a universal that is disclosed only through the particular, as history. That is, he opens up a finite expanse of time as the medium in which ethical human subjects will write out in (proleptic) actions the divinely ordered structure of the universe, as it will be materially disclosed at the end of time.

Tasso's defense of the intellectual Truth disclosed by the sensible signs of poetic imagery thus provides Milton with a corridor to the more thoroughgoing materialism of Francis Bacon, who argues that technological mastery of nature will repair the ruins of the Fall, offering in the preface to the Novum Organum, a sense-based empiricism through which that mastery may be attained:

I propose progressive stages of certainty. The evidence of the sense, helped and guarded by a 
certain process of correction, I retain. But the mental operation which follows the act of sense I for the most part reject; and instead of it I open and lay out a new and certain path for the mind to proceed in, starting directly from simple and sensuous perception. $(8,60)$

By positing a prior, interior and intellectual certainty that is discovered in and by the sensible sign, Tasso and Milton maintain at once the universality of intellectual form and the epistemological primacy of the material world. By rendering things as signs, while preserving them as material things, they join Bacon in enhancing the prestige of particulars experienced through the senses, and, like him, they propose to reclaim the precedent of universal insight by a subsequent accumulation of sensory perceptions.

Peculiar to Milton, however, is the emphasis he gives to the mastery of poetry as a craft, with its own integral history and immanent laws. This craft must be acquired through "labour and intent study" before even the truth that arrives in the form of an "inward prompting" (Prose 1,810 ) can be transformed into words having the "power to perfect" by stimulating "intellect pure and simple." The studious labor invoked in The Reason of Church Government resembles the nightly activities of Il Penseroso, and illuminates his expectation that "old experience" will eventually "attain / To something of prophetic strain" (ll. 173-4). For Milton the senses, and the mundane experiences that reach us through them, provide the raw materials for a divinely ordered process that appropriates his labor to the production of prophetic poems. Such poetry uses material signs to stimulate a "universal insight into things," "the more / To magnifie his works, the more we know" (Paradise Lost 7, 96-7). By putting his talents to work in this way, Milton remembers that "God even to a strictnesse requires the improvement of these his entrusted gifts," and he accepts the burden, which he had described in The Reason of Church Government, of "dispos[ing] and employ[ing] those summes of knowledge and illumination, which God hath sent him into this world to trade with" (Prose 1, 801).

The abilities necessary to shoulder this burden are themselves:

the inspired guift of God rarely bestow'd, but yet to some (though most abuse) in every Nation: and are of power beside the office of a pulpit, to imbreed and cherish in a great 
people the seeds of vertu, and publick civility, to allay the perturbations of the mind, and set the affections in right tune .... (Prose 1, 816-7)

The comment about the common abuse of divine inspiration suggests Milton's awareness of the compounding, in his theory, of mundane and divine sources of poetic truth, of works and grace, disposition and invention. For the divine afflatus without which the poet can create no more than "verbal curiosities" (Prose $1,811-2$ ) is subject to his or her personal abuse and must be received with and dispersed through an austere collaborative effort.

Had Milton not commented upon this collaboration of divine inspiration and dogged human labor, the recipient of Platonic furor poeticus and the rhetorical craftsman would have remained side by side, an internal contradiction in Milton's explanation of his own genius and of poetic genius as such. By insisting that study and labor must develop a "genial nature," and act on "inward promptings," Milton turns this potential contradiction into the fruitfully inverted rhetoric of "subsequent precedence." The temporal predicament figured in narrative history thus writes itself out as a thematics of work.

When the muse inspires an "unpremeditated verse," its assistance is felt principally with invention. Divine revelation supplies the poet with the material about which he writes. Its arrangement and presentation are the province of poetry, conceived of as a self-consistent art, with its own integral history and immanent laws. The ability to master these laws is a God-given gift, but attaining and developing such mastery is hard, socially productive, work.

It is these workaday aspects of poetry that Milton calls style, and for which he rather proudly takes credit, and, rather diffidently, takes responsibility. Thus he reports, in The Reason of Church Government, that from an early age his teachers found of his verse in particular that "the stile by certain vital signes it had, was likely to live" (Prose 1, 809), that, during his 1638 tour, the Italians had further confirmed this stylistic talent, and that, in response to the urging of friends, combined with an "inward prompting," "[he] apply'd [him] selfe ... to fix all the industry and art [he] could unite to the adorning of [his] native tongue" (Prose 1, 811). 
Both Milton's poetic practice and the procedures of typological exegesis common in his day - in which Old Testament history is read as the shadowy sign of New Testament truth - suggest that the work of recognizing and interpreting the "best and sagest things" at once presupposes and produces divine revelation. To attain a "universal insight into things," one needs to know not just what they mean at the moment, but also what they have meant in the past and what they will have meant in the future. One must be both within and without history, experiencing the unfolding sequence of historical causes and reflecting upon their meaning from perspective of subsequent precedence. A poet gifted with a divine revelation, must dispose it in such a way as to represent the eternal through the sequential unfolding of language:

Immediate are the acts of God, more swift

Than time or motion, but to human ears Cannot without proces of speech be told, So told as earthly notion can receive. (P.L. 7, 176-9)

What unfolds sequentially in language, especially, in the form of narrative, has a beginning, a middle and an end. What is universal and divine is a design that encompasses that end from the beginning, a logical end that predestines the temporal one. Thus a prophetic rhetoric comprehends sequence as consequence, explains the beginning through the end. In this very specific sense, Milton's rhetorical poetics are at once subsequent and precedent to knowing God aright.

And, when Milton wants to define the social power of the book, to whom should he allude but Thoth, the bringer of the alphabet, appearing this time in the quise of Cadmus, who brought phonetic writing to the Greeks:

For Books are not absolutely dead things, but doe contain a potencie of life in them to be as active as that soule was whose progeny they are; nay they do preserve as in a violl the purest efficacie and extraction of that living intellect that bred them. I know they are as lively, and as vigorously productive, as those fabulous Dragons teeth; and being sown up and down, may chance to spring up armed men." (Prose 2, 492)

In the England of 1644, there was nothing particularly theoretical about books chancing "to spring up armed 
men," about the realization of ideas in and through the most violently material of mundane actions.

When, in "Of Education," Milton stutters over the subsequence or precedence of poetics, he brings to the surface the intimate and violent connection between the medium of poetry and the Christian assimilation of the unfolding sequence of historical events to an always already completed providential design. The performative power of such a proleptically realized design - be it providential, conspiratorial, ironic - lies in the insistence that unfolding events unfold according to it. It is a form of this violence that renders uncanny the rubse-reading of Bill Readings' near identification with the shipwrecked Edward King with which I began. The question is, how to achieve historical agency without placing the subject on "a fulcrum between predictive historical determinism and sheer contingency." How to rescue ourselves from the cheapness of the uncanny and still be - reponsibly ourselves?

\section{Works Cited}

Bacon, Francis. The Works of Francis Bacon, collected and ed. by James Spedding, Robert Leslie Ellis and Douglas Denon Heath. 13 vols. Boston, 1863.

Derrida, Jacques. Disseminations, trans. Barbara Johnson. Chicago, 1981.

Ficino, Marsilio. The Philebus Commentary, ed. and trans. Michael J. B. Allen. Berkeley, 1975.

Grossman, Marshall. "Authors to themselves": Milton and the Revelation of History. Cambridge: Cambridge University Press, 1987.

Grossman, Marshall. "The Fruits of One's Labor in Miltonic Practice and Marxian Theory," ELH 59 (1992): 77-105.

Haskin, Dayton. Milton's Burden of Interpretation. Philadelphia: University of Pennsylvania Press, 1994.

Milton, John. The Poems of Milton, ed. John Carey and Alastair Fowler. London, 1968.

Milton, John. Complete Prose, ed. Don M. Wolfe, et. al., 8 vols. New Haven and London, 1953-82. 
Readings, Bill. "'An Age too Late': Milton and the Time of Literary History," Exemplaria 4 (1992): 455-68.

Readings, Bill. "Canon and On: From Concept to Figure," Journal of the American Academy of Religion 57 (1989): 149-72.

Readings, Bill. "Hamlet's Thing," in New Essays on Hamlet, ed. Mark Thornton Burnett and John Manning. New York: AMS Press, 1994, 47-65.

Readings, Bill. Introducing Lyotard: Art and Politics. London and New York: Routledge, 1991.

Readings, Bill. "Milton at the Movies: An Afterword to Paradise Lost," in Postmodernism Across the Ages: Essays for a Postmodernity that Wasn't Born Yesterday, ed. Bill Readings and Bennet Schaber. Syracuse, NY: Syracuse University Press, 1993, 88-106.

Readings, Bill. "Postscript: It's a Fair Cop," Exemplaria 4 (1992): 488-92.

Readings, Bill. "When Did the Renaissance Begin? The Henrician Court and the Shakespearean Stage," in Rethinking the Henrician Era, ed. Peter C. Herman. Urbana and Chicago: University of Illinois Press, 1994, 283-302.

Tasso, Torquato. Discourses on the Heroic Poem, trans. Mariella Cavalchini and Irene Samuel. Oxford, 1973.

\section{NOTES}

1. Marsilio Ficino, The Philebus Commentary, ed. and trans. Michael J. B. Allen (Berkeley: University of California Press, 1975).

2. See Readings, "Hamlet's Thing."

3. Jacques Derrida, 13.

4. See Derrida, 44: "As double derived from some primal unit, as image, imitation, expression, representation, the book has as its origin, which is also its model, outside itself: the "thing itself" or that determination of what exists that is called "reality," as it is perceived or thought 
by the one who describes or inscribes. Reality present, then, or reality represented, this alternative is itself derived from a prior model. The Model of the Book, the Model Book, doesn't it amount to the absolute adequation of presence and representation, to the truth (homiosis or adaequatio) of the thing and of the thought about the thing, in the sense in which truth first emerges in divine creation before being reflected by finite knowledge? Nature, God's Book, appeared to the medieval mind to be a written form consonant with divine thought and speech, true to God's attentive understanding [entendement, lit. "hearing"] as Logos, the truth that speaks and hears itself speak, the locus of archetypes, the relay point of the topos noeto or the topos ouranios. A writing that was representative and true, adequate to its model and to itself, Nature was also an ordered totality, the volume of a book weighty with meaning, giving itself to the reader, which must also mean the hearer, as if it were a spoken word, passing from ear to ear and from mind to mind [d'entendement à entendement]. "The eye listens" (Claudel) when the book has as its vocation the proffering of divine logos." See also, Bill Readings, "Hamlet's Thing, " 55-60.

$\underline{\mathbf{5}}$. On Milton's extensive use of the parable of the talents to interrogate his own life, see Dayton Haskin, Milton's Burden of Interpretation.

6. It should be noted that writing makes visible as space the temporal sequentiality of speech. Thus writing itself performs upon speech the same presencing of the future that prophetic rhetoric will perform upon History. See Readings, "Milton at the Movies": "Milton's poetic work is not simply the negative moment of the modernist project; it is the radical disturbance of an assured relationship between language and time. Milton, that is, is not Saussurean avant la lettre, but one who, by virtue of a certain poetic labor, poses the question that the letter may have no avant, who insists upon the difficulty of the time of writing, the irreducibility of the event of writing to the modernist writing (description) of the event within the framework of a single history" (91). See also, Readings, "Canon On," 155-57.

Accueil Surfaces | Table des matières | Recherche $\underline{\text { Surfaces Home Page | Table of Contents | Search }}$

PUM | Livres | Revues | Publications électroniques | Vente et distribution 